\title{
No. XXIV.-ON THE FERNS OF THE SEYCHELLES AND THE ALDABRA GROUP *.
}

By Carl Christensen, M.Sc. (Copenhagen).

(Communicated by Professor J. Stanley Gardiner, M.A., F.R.S., F.L.S.)

(Plate 25.)

Read 6th June, 1912.

ON the suggestion of Dr O. Stapf, Keeper of the Herbarium and Library, Royal Botanic Gardens, Kew, I undertook the determination of a collection of ferns made in the Seychelles by Professor J. Stanley Gardiner during the 'Sealark' Fxpedition in 1908, and the preparation of a complete list of the ferns of the Seychelles. It is true, the islands are not a terra nova for pteridography ; nevertheless a revision of the fern-fiora of the islands was thought desirable so as to bring it into line with modern ideas of pteridography.

The ferns of the Seychelles have been dealt with twice by J. G. Bakert, and later on by M. Kuhn $\$$, who published a list of the ferns occurring in the islands. Whilst Baker knew 74 species of true ferns indigenous in the island, Kuhn enumerated 76 species, and my list includes 78 species.

It was an easy task to name the specimens in accordance with Baker's treatment, but as my ideas of the delimitation of not a few species differ essentially from those of Baker, who takes the species in a much broader sense, I examined the material critically and compared it with specimens which the authorities of Kew kindly forwarded to me for that purpose. For this my best thanks are due to Sir David Prain and Dr Stapf. As will be seen, I do not agree with all of Baker's determinations, and therefore my list differs in certain points from his. My nomenclature too is, of course, very different from his. With few exceptions, I follow the nomenclature of my 'Index Filicum,' which is quoted under each species. In that work the essential synonyms and references will also be found, wherefore it is unnecessary to repeat them here.

So far as is known, the Seychelles are inhabited by 78 species of ferns, all but one (Ceropteris calomelanos, which probably is introduced) indigenous in the islands. All these species were collected in the higher islands, Mahé and Silhouette; three or four were also found in Bird Island and Long Island. No fern is known from the other islands (Praslin, La Digue, and Curieuse). Prof. Gardiner has added four species to the fern-flora of the islands.

* Reprinted from Trans. Linn. Soc., ser. 2, Bot., vol. vii. pp. 409-25, pl. 45, 1912.

† J. G. Baker: "On the Seychelles Fern-Flora," in Trans. R. Irish Acad. vol. xxv. (1875), pp. 509-518, tabb. 28-31; 'Flora of Mauritius and the Seychelles' (1877).

$\ddagger$ M. Kuhn : Cryptogamæ vasoulares, in 'Botanik von Ost-Afrika' in Von der Decken's Reisen, vol. iii. part 1 (1879), pp. 68-69.

SECOND SERIES-ZOOLOGY, VOL. XV. 
The composition of the fern-flora of the Seychelles is of some interest, because the group is situated so far east from the African continent. 'The following table shows the

\begin{tabular}{|c|c|c|c|}
\hline \multicolumn{4}{|c|}{ Species of Westeren Distribution. } \\
\hline $\begin{array}{c}\text { American species extending } \\
\text { eastwards to tropical } \\
\text { Asia: } 4 .\end{array}$ & $\begin{array}{c}\text { American species extending } \\
\text { eastwards to the } \\
\text { Seychelles: } 5 \text {. }\end{array}$ & $\begin{array}{l}\text { Species confined to Africa } \\
\text { and the South-eastern } \\
\text { African islands: } 10 .\end{array}$ & $\begin{array}{l}\text { Species confined to the } \\
\text { South-eastern African } \\
\text { islands : } 6 \text {. }\end{array}$ \\
\hline $\begin{array}{l}\text { Hymenophyllum polyanthos. } \\
\text { H. ciliatum. } \\
\text { Elaphoylossum petiolatum. } \\
\text { E. spathulatum. }\end{array}$ & $\begin{array}{l}\text { Polypodium serrulatum. } \\
\text { P. cultratum. } \\
\text { Elaphoglossum martinicense. } \\
\text { E. latifolium. } \\
\text { Ophioglossum palmatum. }\end{array}$ & $\begin{array}{l}\text { Trichomanes erosum. } \\
\text { Oleandra articulatis. } \\
\text { Davallia chcerophylloides. } \\
\text { Stenochlcena tenuifolia. } \\
\text { Pellea Doniana. } \\
\text { P. viridis. } \\
\text { Pteris atrovirens. } \\
\text { Adiantum rhizophorum. } \\
\text { Lonchitis pubescens. } \\
\text { Vittaria isoetifolia. }\end{array}$ & $\begin{array}{l}\text { Hymenophyllum hygrometricum. } \\
\text { Dryopteris strigosa. } \\
\text { D. mauritiana. } \\
\text { Aspidlium pleiotomum. } \\
\text { Diplazium sechellarum. } \\
\text { Monogramma graminea. }\end{array}$ \\
\hline $\begin{array}{l}\text { SPECIES ENDEMIC IN THE } \\
\text { SEYCHELLES }: 12 .\end{array}$ & \multicolumn{2}{|c|}{ Species of Eastern Distribution. } & Cosmonolitan SPECIES: 11. \\
\hline $\begin{array}{l}\text { Cyathea sechellarum. } \\
\text { Dryopteris Hornei. } \\
\text { D. Wardii. } \\
\text { Leptochilus bipinnatifidus. } \\
\text { Lindsayce Kirkii. } \\
\text { L. Hornei. }\end{array}$ & $\begin{array}{l}\text { Species extending from } \\
\text { tropienl Africa to } \\
\text { Polynesia: } 18 .\end{array}$ & $\begin{array}{l}\text { Polynesian-Asiatic species } \\
\text { reaching westwards to the } \\
\text { South-eastern African } \\
\text { islands, not in contiuental } \\
\text { Africa: } 10 .\end{array}$ & $\begin{array}{l}\text { Dryopteris parasitica. } \\
\text { Polystichum adiantiforme. } \\
\text { Nephrolepis cordifolia. } \\
\text { N. hiserrata. } \\
\text { Asplenium lunulatum. } \\
\text { A. caudatum. }\end{array}$ \\
\hline $\begin{array}{l}\text { Asplenium complanatum. } \\
\text { Stenochlcena Pervillei. } \\
\text { Pleris Barklyo. } \\
\text { Polypodium Pervillei. } \\
\text { P. albobrunneum. } \\
\text { Elaphoglossum Hornei. }\end{array}$ & $\begin{array}{l}\text { Microlepia spelunca. } \\
\text { Silizoloma ensifolium. } \\
\text { Asplenium nidus. } \\
\text { A. unilaterale. } \\
\text { Adiantum caudatum. } \\
\text { Actiniopteris australis. } \\
\text { Pteris tripartita. } \\
\text { Vittaria elongata. } \\
\text { V. scolopendrina. } \\
\text { Hymenolepis spicata. } \\
\text { Polypodium punctatum. } \\
\text { P. phymatodes. } \\
\text { Cyclophorus spissus. } \\
\text { Platycerium bifurcatum. } \\
\text { Ceratopteris thalictroides. } \\
\text { Gleichenia linearis. } \\
\text { Marattia fraxinea. } \\
\text { Angiopteris evecta. }\end{array}$ & $\begin{array}{l}\text { Trichomanes cupressoides. } \\
\text { Dryopteris cucullata. } \\
\text { Odontosoriat chinensis. } \\
\text { Asplenium tenerum. } \\
\text { A. affine. } \\
\text { A. bulbiferum. } \\
\text { Antrophyum immersum. } \\
\text { A. callifolium. } \\
\text { Schizaca digitata. } \\
\text { Ophioglossum pendulum. }\end{array}$ & $\begin{array}{l}\text { Pteris biaurita. } \\
\text { P. quadriaurita. } \\
\text { Histiopteris incisa. } \\
\text { Elaphoglossum conforme. } \\
\text { Acrostichum aureum. }\end{array}$ \\
\hline
\end{tabular}

distribution of the different species. Not considering the 11 cosmopolitan species, the remaining 65 species can be sorted into three groups :-

I. $9(4+5)$ species have their centre in tropical America, 5 of these reaching their eastern limit in the Seychelles. 
II. $28(10+6+12)$ are confined to Africa, including the islands; 18 of these are not found in tropical Africa, but are endemic in the South-eastern islands, and 12 species are endemic in the Seychelles. Nearly all these endemic species may be regarded as specialized forms of groups which are richly developed in other regions, perhaps with the exception of Pteris Barklyce, a peculiar species, which is probably most closely related to the Mascarene Ochropteris. If we take the relationship of the endemic species into consideration, we find that some of them point westwards (Dryopteris Wardii, Polypodium Pervillei, Elaphoglossum Hornei), others eastwards (Leptochilus bipinnatifidus, Lindsaya Kivkii, L. Hornei), while Asplenium complanatum, Stenochlcenc Pervillei, and perhaps Polypodium albobrunneum are members of groups specially developed in the Mascarene and other South-eastern African islands.

III. $28(1.8+10)$ species have their maximum in tropical Asia and Polynesia; 10 of these reach their western limit in the South-eastern African islands, and among these there are 4 species (Asplenium tenerum, A. bulbiferum, Antrophyum callifolium, and Schizae digitata) which have their western boundary in the Seychelles.

The above may be summarized thus: the fern-flora of the Seychelles is a mixture of western and eastern species, the latter being in majority. Five species here reach their eastern limit, four their western. The fern-flora as a whole shows no peculiar character; 16 per cent. of the species are endemic.

From the Aldabra group only one species is known. the common mangrove fern, Acrostichum aureum.

\section{HYMENOPHYLLACEÆ.}

1. Trichomanes enosum, Willd. (P); Baker, Fl. Maur. 464; C. Chr. Ind. 639.? T. cuspidatum, Kuhn, Bot. v. Ost-Afr. 68.

Common in the mountain forests, Horne. Silhouette, 2000 feet on trees, Gardiner!

It is with the greatest doubt that I refer the specimens from the Seychelles to T. erosum, Willd., which is a West-African species. In general habit the small leaves agree much more with $T$. cuspidatum, Willd., but they differ in the lack of an intramarginal, spurious vein and in the more distinct midrib and lateral veins. The fronds vary in shape, from circular and entire to triangular-oblong, $3 \mathrm{~cm}$. long by $1-1 \frac{1}{4} \mathrm{~cm}$. broad, and irregularly repand or serrate, not regularly pinnatifid as in the true $T$. erosum. The form may be specifically distinct from $T$. erosum as well as from $T$. cuspidatum.

2. Trichomanes cupressoides, Desv. Prodr. 330, 1827 ; C. Chr. Ind. 638.-T. obscurum, var. pectinata, Mett.; Kuhn, Fil. Afr. 35. T. rigidum, Baker, Fl. Maur. 465.

Mahé, Silhouette, and Long Island, Gardiner! A typical fern on rocks on mountains, 2000-2500 feet. 
This species, which was originally described from plants from the Seychelles, is common in all the South-east African islands. The Malayan T. obscurum, Blume, is very similar and very likely not specifically different.

3. Hymenophyllum polyanthos, Sw.; Baker, Fl. Maur. 462; C. Chr. Ind. 366.

Mahé, Horne, 146 ! Gardiner! Silhouette, on trees, 2000 feet, Gardiner!

Also found in Madagascar and tropical West Africa and widely spread in tropical America. A closely allied species, $H$. Blumeanum, Spr., occurs in tropical Asia.

4. Hymenophyllum ciliatum, Sw.; Baker, Fl. Maur. 462 ; C. Chr. Ind. 358. Mahé, Gardiner! Widely spread in the tropics.

5. Hymenophyllum hygrometricum (Poir.), Desv.; Baker, Fl. Maur. 463 ; C. Chr. Ind. 362.

Mahé, Pervillé, Horne, Gardiner ! in jungle anywhere and at any altitude, on trees or rocks. Silhouette, Gardiner!

The species is confined to the South-east African islands.

\section{CYATHEACE $\approx$.}

6. Cyathea sechellarum, Mett.; Baker, Fl. Maur. 467.

Mahé, Horne, 203 ! Silhouette, Gardiner!

Endemic.-I quote from the labels. Horne says : "Common at and above $1000 \mathrm{ft}$. in Mahé. Trunk in ravines 40-50 ft. Stipe 1-2 ft. Frond 4-9 ft. long, 2-4 ft. broad." Gardiner : "Part of a tree-fern [from the summit of the island of Silhouette, above $2120 \mathrm{ft}$.]. There are no trunks ; the base rising only about 6 in. above ground." Gardiner's specimen is sterile and may, of course, have been taken from a young plant without a developed caudex. It is surprising that Gardiner did not collect the species in Mahé, where in 1871 it was common, according to Horne, which suggests that it is nearly or quite extinct. [It is still found in the indigenous jungles of the hilltops of Central Mahé, but is disappearing. It was in a press from Mount Harrison which went astray.-J. S. G.]

\section{POLYPODIACE无.}

7. Dryopteris STRIgosa (Willd.), C. Chr. Ind. 295.-Aspidium strigosum, Willd.; Kuhn, Bot. v. Ost-Afrika, 37. Nephrodium tomentosum, Baker, Fl. Maur. 496, pro parte.

I list this species with some doubt among the ferns of the Seychelles, as I have seen only a single, rather scanty specimen from the islands (Horne, 678), determined by Baker as Nephrodium tomentosum. It does not belong to the true Dryopteris tomentosa (Thouars), but rather to D. strigosa (Willd.), according to Kuhn's delimitation of that species. Still the determination is rather doubtful, the basal pair of veins is truly united. The species is known from the Mascarenes and Madagascar. 
8. Dryopteris Parasitica (Linn.), O. Kuntze; C. Chr. Ind. 282.-Nephrodium molle, Baker, Fl. Maur. 499.

Mahé, Horne, 202 !

The species trken in a broad sense is common in all tropical and subtropical regions. The form growing in the Seychelles is scarcely conspecific with the common American D. mollis (Jacq.), Hieron.

9. Dryopteris cocullata (Blume), Christ, Philippine Journ. Sci. Bot. ii. 194, 1907.Nephrodium cucullatum, Baker, Fl. Maur. 498. Dryopteris unita (Linn.), O. Kuntze ; C. Chr. Ind. 299.

Mahé, Silhouette, and Long Island, Gardiner! Typical fern of open spaces, 1000-2000 feet.

Distribution. Through tropical Asia and Polynesia, and common in the South-east African islands.

10. Dryopteris mauritiana (Fée), C. Chr.-Nephrodium elatum, var. mauritianum, Baker, Fl. Maur. 499.-Aspidium procerum, Bojer ; Kuhn, Bot. v. Ost-Afrika, 41 (with description).

Var. GARDINERI, C. Chr. (var. nov.).

A forma typica differt: pinnis brevioribus, ad $12 \mathrm{~cm}$. longis $2 \mathrm{~cm}$. basi latis, atroviridibus, tenuiter membranaceis, ad costas costulasque supra albido-setosis, infra breviter et sparse hirtis, inter venas utrinque glabris, infra glandulis sessilibus subdense glandulosis; laciniis vix obliquis, obtusis; venis 8-10-jugis, pellucidis, basalibus 2-4 alternatim unitis; indusiis magnis, glabris.

Silhouette, Gardiner, Aug. 2, 1908. Mahé, H. P. Thomasset (this is more like the type).

The typical form of $D$. mauritiana was found previously in the Mascarenes and Comoros. The species is new to the Seychelles. The single leaf collected measures $1 \frac{1}{2} \mathrm{~m}$. in length on a stipe scarcely $10 \mathrm{~cm}$. long; it narrows downwards rather gradually through about 15 pairs of auriculiform pinnæ, $\frac{1}{2}-2 \mathrm{~cm}$. long and broad, and hastate. It differs from the type mainly in the glandular underside and its patent, obtuse segments. The pinnæ taper from a broad base towards the acuminate apex.-I am inclined to believe that Aspidium elatum, Bojer, from Mauritius is specifically distinct.

11. Dryopteris W WRDIr (Baker), O. Kuntze; C. Chr. Ind. 301.-Nephrodium Wardii, Baker, Trans. R. Irish Acad. xxv. (1875), tab. 30; Fl. Maur. 496.

Mahé, Ward! Horne, 177! Gardiner! Silhouette, Gardiner!

Endemic. Rhizome horizontal, about $2 \mathrm{~cm}$. thick, densely covered with glossy, brown, narrow acuminate scales, 1-2 cm. long. Stipe about $25 \mathrm{~cm}$. long, slightly scaly at the base. Lamina about $50 \mathrm{~cm}$. long, $40 \mathrm{~cm}$. broad at the base, entirely glabrous. In habit not unlike D. effusa (Sw.), Urban, of tropical America. 
12. Dryopteris Hornei (Baker), O. Kuntze; C. Chr. Ind. 271.-Nephrodium Hornei, Baker, Fl. Maur. 497.

Mahé, Horne, 182 ! Silhouette, Horne, 685 !

Endemic. The pubescence is peculiar, the costæ and costulæ above are rufous-tomentose from short, articulated hairs (the typical pubescence of my subgenus Ctenitis); the veins beneath are densely covered with very short and thick, appressed glandular hairs, which in well-preserved specimens are glossy, golden yellow, in old specimens whitish, meal-like. I remember only one species which shows a similar pubescence, viz. D. chrysotricha (Baker), C. Chr., from Samoa, but in that the hairs are bright yellow.

13. Aspidicm Pleiotomum (Baker), Kuhn; C. Chr. Ind. 88.-Nephrodium pleiotomum, Baker, Tr. Roy. Irish Acad. xxv. (1875), tab. 31 в; Fl. Maur. 500.

Mahé, Horne. Silhouette, Gardiner!

Also Madagascar, fide Baker.

14. Polystichum adiantiforme (Forst.), J. Sm.; C. Chr. Ind. 578.-Aspidium capense, Willd.; Baker, Fl. Maur. 492. Aspidium coriaceum, Sw.; Kuhn, Bot. v. OstAfrika, 69.

Mahé and Silhouette, Gardiner! Sometimes partially epiphytic.

Distribution. Australia and Southern Polynesia. South Africa and adjacent islands. America from Cuba and Jamaica to Fuegia. A common species in most oceanic islands of the southern hemisphere. The numerous specimens collected by Gardiner are rather different, especially in size; some of them are scarcely more than bipinnatifid with a lamina not more than $10 \mathrm{~cm}$. long, but fully fertile.

15. Leptochilus Bipinnatifidus (Mett.), C. Chr. comb. nov.-Chrysodium bipinnatifidum, Mett.; Kuhn, Fil. Afr. 50. Acrostichum repandum, Baker, Fl. Maur. 514 (non Blume).

Mahé, Boivin! Gardiner! Silhouette, near the summit, Gardiner!

Perhaps endemic. It is also recorded from Réunion (coll. Boivin); but Jac. de Cordemoy has not seen it. All Boivin's specimens in the Museum of Paris seen by me are from the Seychelles.

I now think that this can safely be regarded as a species distinct from the Asiatic arid Polynesian L. cuspidatus, C. Chr. (Acrostichum repandum, Blume). It differs in the more deeply cut pinnæ, which are truncate at the base, not cuneate, and in the more decidedly scaly costæ. The lowermost pinnæ are rather unequal-sided, the upper ones decurrent at the lower base, and the fertile pinnæ deeply cut into bluntly rounded lobes. The sterile fronds often have rooting tips.

16. Oleandra articulata (Sw.), Presl ; Baker, Fl. Maur. 493 ; C. Chr. Ind. 466.

Mahé, Gardiner! Silhouette, near the summit, Gardiner! "Epiphytic, notable climber."

Distribution. Through tropical Africa to Cape Colony, and especially common in the South-east African islands. 
17. NePhrolepis cordifolia (Linn.), Presl ; Baker, Fl. Maur. 493 ; C. Ohr. Ind. 453.N. tuberosa, Presl ; Kuhn, Bot. v. Ost-Afr. 69.

Seychelles, teste Brker. A cosmopolitan tropical species.

18. NePhrolepis biserrata (Sw.), Schott; C. Chr. Ind. 453.-N. exaltata, var. biserrata, Baker, Fl. Maur. 493.

Mahé, Silhouette, Long Island, Bird Island, Gardiner!

19. Humata Repens (Linn. f.), Diels; C. Chr. Ind. 354.-Davallia pedata, Sw.; Baker, Fl. Maur. 468.

Mahé and Silhouette, Gardiner! Climber, dominant near the tops of trees; also in moss of the highest jungle in open places, Morne Pilot, 2700 feet, Mahé.

Distribution. From the South-east African islands through tropical Australia and Asia to Japan.

20. Davallia cherophrlloides (Poir.), Steud.; C. Chr. Ind. 208.-D. elata, Baker, Fl. Maur. 469. D. denticulata, var. intermedia, Mett. ; Kuhn, Fil. Afr. 158.

Mahé and Silhbuette, Gardiner! Common in jungle, everywhere. In Silhouette it is said to be "a glacis fern, growing in moister holes in the rock." The fertile frond is densely glandulose throughout. The species is an African representative of and nearly related to the Asiatic and Polynesian D. denticulata (Burm.), Mett.; it is known from tropical West Africa, Natal, the Comoros, Madagascar, Mauritius, Rodriguez, and the Seychelles.

21. Microlepia speluncex (Linn.), T. Moore; C. Chr. Ind. 428.-Davallia spelunca, Baker, Fl. Maur. 469.

Mahé, Gardiner! Thomasset!

Cosmopolitan in the tropics of the Old World.

22. Odontosoria chinensis (Linn.), J. Sm.; C. Chr. Ind. 464.--Lindsaya chinensis, Mett.; Kuhn, Fil. Afr. 67. Davallia tenuifolia, Sw.; Baker, Fl. Maur. 469.

Seychelles (fide Baker, not seen).

Distribution. From Japan through tropical Asia and Polynesia and again in the South-east African islands.

23. Schizoloma ensifolidm (Sw.), J. Sm.; C. Chr. Ind. 618.-Lindsaya ensifolia, Sw.; Baker, Fl. Maur. 472. Mahe, Gardiner! Thomasset!

Distributed through the tropics of the Old World. 
24. Lindsaya Kinkit, Hook.; Baker, Trans. R. Irish Acad. xxv. (1875), tab. 28; Fl. Maur. 473 ; C. Chr. Ind. 394.-L. Pervillei, Mett. ; Kuhn, Fil. Afr. 17 et 68.

Mahé, Gardiner! Thomasset. Silhouette, Gardiner!

Endemic. A large pretty species, common in the islands, growing on the ground and often partially epiphytic.

25. Lindsaya Honnei (Baker), C. Chr. Ind. 210 (omitted under Lindsaya).-Davallia Hornei, Baker, Fl. Maur. 470.

Mahé, Horne, 677 !

Endemic, common fide Horne, but not collected by Gardiner. It is a true Lindsaya, but a rather problematic species. It is, perhaps, a small form of $L$. Kirkii, with which it agrees in soral characters and basal scales; still the shape of the segments is somewhat different, their lower edge being much upcurved while in $L$. Kirkii it is decurved.

26. Diplazidm sechellarum (Baker), C. Chr. Ind. 238.-Asplenium sechellarum, Baker, Fl. Maur. 491.

Mahé, Bouton! Horne! "Common in the damp shady forests," but not collected by Prof. Gardiner.

According to Baker also found in Madagascar. It is a large, tripianatifid species, related to the Asiatic D. polypodioides, Blume, characterized by the muncated rachis.

27. Asplentum Nidus, Linn.; Baker, Fl. Maur. 491; C. Chr. Ind. 123.

Mahé, Gardiner! Thomasset! Silhouette, Gardiner!

Distribution. Through tropical Polynesia, Australia, and Asia, extending westwards to tropical West Africa.

28. Asplenium unilaterale, Lam.; C. Chr. Ind. 136.-A. resectum, Sm.; Baker, Fl. Maur. 485.

Seychelles, Kirk!

Distribution. Through the tropics of the Old World.

29. Asplenitu lundlatum, Sw.; Baker, Fl. Maur. 486.

Mahé, Horne, 404 (not seen).

Distribution. Regarded as a collective species, $A$. lunulatum is widely spread through the tropics; the typical form is South African.

30. Asplenidm tenertm, Forst.; Baker, Fl. Maur. 486 ; C. Chr. Ind. 134.

Mahé, Horne, 684 !

Spread through tropical Polynesia and Asia; it is not known from the other African islands.

31. Asplenidm (Euasplenium) complanatum, C. Chr. (sp. nov.). (Pl. 25, figs. 1-3.)

Rhizoma obliquum, fere $1 \mathrm{~cm}$. crassum, squamis parvis, ovatis, nigrescentibus, subdense onustum. Stipites numerosi, subapproximati, virides, glabri, complanati, supra late 
canaliculati, sursum anguste alati, ad $7 \mathrm{~cm}$. longi. Lamina pinnata, lanceolata, usque ad $20 \mathrm{~cm}$. longa, $5 \mathrm{~cm}$. lata, versus apicem pinnatifidum seu grosse serratum, breviter acuminata, viridis, omnino glabra, textura carnosula. Rachis complanata, a basi ad apicem alata, alis $1 \mathrm{~mm}$. latis. Pinnce numerosæ, $2 \frac{1}{2} \mathrm{~cm}$. longæ, $1 \mathrm{~cm}$. latæ, suberectæ, inferiores vix abbreviatæ, breviter petiolatæ, ad rachin articulatæ, basi inferiore cuneatæ, superiore truncatæ, sæpe subauriculatæ, marginibus apiceque obtuso grosse serratis. Venæ indistinctæ, simplices, obliquæ. Sori mediales, 1-2 mm. longi, $1 \mathrm{~mm}$. lati, indusiis margine integris.

Silhouette, Gardiner!

This new species resembles the Australian $A$. obtusatum, Forst, in colour and texture and the short thick sori, but in general habit it is not unlike $A$. tenerum, from which it differs in its short sori, fleshy texture, and winged rachis. It is a well-known fact that several pinnate species of Asplenium vary extraordinarily in cutting. The most cut forms are often dareoid, $i$.e. the ultimate segments are narrow with the sori marginal. Such dareoid varieties look very different from the pinnate forms of the same species, and they are commonly described as proper species. It has, however, been proved by botanists who have studied the different forms in the field that certain old species of Darea really are dareoid forms of species which, in the "normal" state, are pinnate only. Thus is Darea bifida, Bory, the dareoid variety of A. lineatum, Sw.; D. Belangeri, Bory, of $A$. tenerum. Dareoid forms are especially common in the Mascarenes and South Africa, and some of them are not known in the pinnate state. My proposed new species, $A$. complanatum, may be the pinnate form of a species which so far is known as dareoid only, viz. Asplenium borbonicum, Hook., a species from Réunion and Mauritius, but not known from the Seychelles. It is very probable that such is the case, but I cannot prove it at present, and I therefore think it best to describe the new form as a new species.

32. Asplenium caddatum, Forst.; Baker, Fl. Maur. 488; C. Chr. Ind. 104.

Mahé, Horne, 668! Thomasset! Silhouette, Gardiner! "A typical fern of the 1000-2000 feet zone in fairly open places."

Var. MINoR, C. Chr. (var. nov.):-Lamina $20 \mathrm{~cm}$. longa, pinnis $3 \mathrm{~cm}$. longis, $\frac{1}{2}-1 \mathrm{~cm}$. latis, apice acutis nec caudatis.

Mahé and Silhouette, Grardiner!

This variety is a very doubtful form, in size and general habit very much resembling A. pellucidum, Lam., to which species Baker (Fl. Maur. 487) referred a specimen from the Seychelles (coll. Kirk!). It differs from that species in its lower pinnæ being not at all reduced. I think I am right in considering it a small form of $A$. caudatum, from which it differs in its small size and non-caudate pinnæ, whilst it agrees with it in colour, texture, pubescence, and other characters. A specimen from Silhouette (Gardiner) is exactly intermediate between the large $A$. caudatum and the variety.

A. caudatum is a cosmopolitan tropical species.

SECOND SERIES-ZOOLOGY, VOL. XV. 
33. Asplenium affine, Sw.; C. Chr. Ind. 100.-A. cuneatum, var. affine, Baker, Fl. Maur. 489.

Mahé, Gardiner! Thomasset!

Distribution. Common in the South-east African islands; tropical Asia and Polynesia. It may be a variety of $A$. cuneatum, Lam., the typical form of which is West Indian. Some of the leaves are proliferous at the apex (conf. A. viviparioides, Kuhn).

34. Asplenium bulbiferum, Forst.; Baker, Fl. Maur. 489 ; C. Chr. Ind. 103.

Seychelles, Kirk (fide Baker, not seen).

Whether this is the true $A$. bulbiferum, Forst., I cannot say. Kuhn did not list A. bulbiferum as an African species.

35. Stenochlana Pervillei (Mett.), Underw. Bull. Torr. Club, xxxiii. (1906), 49, fig. 1.-Lomariopsis Pervillei, Mett.; Kuhn, Fil. Afr. 53. Acrostichum sorbifolium, Baker, Fl. Maur. 513.

Mahé, Gardiner! Thomasset! ; common over 1000 feet. Silhouette, Gardiner ! ; rare epiphytic climber.

Endemic. The upper base of the sterile pinnæ is commonly nearly parallel to the rachis, and not so cuneate as shown in Underwood's figure quoted above.

36. Stenochlana tendifolia (Desv.), T. Moore; C. Chr. Ind. 626.-Acrostichum tenuifolium, Baker, Fl. Maur. 513. Polybotrya tenuifolia, Kuhn, Fil. Afr. 52.

Seychelles, Pervillé, 464 (fide Kuhn, not seen).

Distribution. Tropical and South Africa, with the adjacent islands.

37. Ceropteris calomelanos (Linn.), Underw.; C. Chr. Ind. 169.

Mahé, Gardiner!

An American species, probably introduced, as in several tropical countries in the Old World.

38. Pellata Doniana, Hook.; Baker, Fl. Maur. 477 ; C. Chr. Ind. 479.

Mahé, Gardiner! Thomasset! Silhouette, Gardiner! "This fern occurs right down in the mangroves at Grande Barbe."

Spread through tropical Africa; not known from the other islands.

39. Pellefa viridis (Forsk.), Prantl ; C. Chr. Ind. 483.-P. hastata, Link ; Baker, Fl. Maur. 478. Pteridella viridis, Mett.; Kuhn, Bot. v. Ost-Afr. 16.

Seychelles (fide Baker, not seen).

Through tropical Africa to the Cape and the South-eastern islands.

40. Adiantum Caddatum, Linn.; Baker, Fl. Maur. 474, part.; C. Chr. Ind. 24.

Seychelles, Kersten, 9 (fide $K u h n$, not seen).

Tropical Africa and Asia. 
41. Adiantum Rhizophorum, Sw.; Kuhn, Fil. Afr. 66 ; C. Chr. Ind. 33.-A. caudatum, part., Baker, Fl. Maur. 474.

Seychelles, Pervillé, 212 (fide Kuhn, not seen).

Southern Africa and adjacent islands.

42. ACtiniopteris australis (Linn. fil.), Link; C. Chr. Ind. 21.-Pteris dichotoma, var. elongata, Mett.; Kuhn, Fil. Afr. 80. P. dichotoma, Baker, Fl. Maur. 481. Actiniopteris dichotoma, Mett.; Kuhn, Bot. v. Ost-Afr. 68.

Seychelles, Pervillé (fide Kuhn, not seen).

Distributed from Africa with the South-eastern islands to tropical Asia.

43. Pteris Barklyes (Hook.), Mett.; Kuhn, Fil. Afr. 77 (as Barkleya).-Pellaa Barklya, Baker, Fl. Maur. 477 ; C. Chr. Ind. 478.

Seychelles, Kirk! Lady Barkly! Gardiner! (Mahé).

Endemic. A very distinct species, the proper place of which must be in the genus Pteris. The essential difference between Pellae and Pteris is the different habit; in soral characters the two genera agree. In Pellaa the sterile tips of the fertile segments are entire, in Pteris nearly always distinctly serrated; in this character the present species agrees with Pteris. It is perhaps nearest related to Ochropteris pallens (Sw.), J. Sm., from the Mascarenes, resembling it closely in cutting, but the sori are truly pteridoid and the rachis is purplish and polished.

44. Pteris biaurita, Linn. ; Baker, Fl. Maur. 481; C. Chr. Ind. 593.

Seychelles (fide Baker, not seen).

45. Pteris biaurita, Linn., subsp. P. quadriaurita, Retz.; Baker, Fl. Maur. 480.$P$. nemoralis, Willd.; Kuhn, Fil. Afr. 86.

Seychelles, Kersten, 20 (fide Kuhn). Mahé, Gardiner!

$P$. biaurita, with its subspecies quadriaurita, is cosmopolitan in the tropics.

46. Piteris atrovirens, Willd.; Baker, Fl. Maur. 482 ; C. Chr. Ind. 593.

Mahé, Horne, 652 (fide Baker, not seen).

Spread through tropical Africa ; not found in the other islands of the Indian Ocean.

47. Pteris tripartita, Sw.; C. Chr. Ind.608.-P. marginata, Bory ; Baker, Fl. Maur. 482.

Silhouette, Gardiner! Pervillé (fide Kuhn).

Spread through the tropics of the Old World.

48. HistiopteRIs ixcisa (Thunb.), J. Sm. ; C. Chr. Ind. 352.-Pteris incisa, Baker, Fl. Maur. 483.

Mahé, Gardiner! Pervillé, 75 (fide $K u h n$ ).

Through the tropics and the southern temperate regions. 
49. Lonchitis pubescens, Willd. ; Baker, Fl. Maur. 475 ; C. Chr. Ind. 409.-L. hirsuta, Kuhn, Bot. v. Ost-Afr. 10.

Seyclielles, Kirk (fide Baker, not seen).

Through tropical and Southern Africa, with the Eastern islands.

50. Monogramma graminea (Poir.), Schkuhr; Baker, Fl. Maur. 501 ; C. Chr. Ind. 430. Seyclielles, Pervillé (fide Kuhn and Baker, not seen).

Confined to the Seychelles and Mascarenes.

51. Vittaria elongata, Sw.. var. ensiformis (Sw.).-V. ensiformis, Sw.; C. Chr. Ind. 653. V. plantaginea, Bory; Kuhn, Fil. Afr. 55. V. elongata, Baker, Fl. Maur. 471. Silhouette, 2000 feet, Gardiner!

The variety is probably confined to the Mascarenes and Seychelles; the species, in several forms, is widely spread through the tropics of the Old World.

52. Vittaria isoetifolia, Bory; Kuhn, Fil. Afr. 55 ; C. Chr. Ind. 654.-V. lineata, Baker, Fl. Maur. 471.

Mahé, Gardiner! Thomasset! Silhouette, Gardiner!

South Africa and adjacent islands. The determination is rather doubtful.

53. Vittaria scolopendrina (Bory), Thwait.; Baker, Fl. Maur. 471 ; C. Chr. Ind. 655. Mahé and Silhouette, near the summit, Gardiner!

Distribution. From Mozambique through tropical Asia to Samoa.

54. Antrophyum immersum (Bory), Mett.; Baker, Fl. Maur. б09; C. Chr. Ind. 60.

Seychelles (fide Baker, not seen).

Mascarenes, Seychelles, and Malesia.

55. Antrophyum callifolium, Blume; C. Chr. Ind. 59.-A. reticulatum, Baker, Fl. Maur. 509.

Mahé, Horne, 683 ! Silhouette, near summit, very scarce, Gardiner!

Distribution. Malesia, Polynesia, Seychelles.

According to Mettenius's description in Ann. Mus. Lugd.-Bat. iv. 171, this is A. callifolium, not $A$. reticulatum (Forst.), Kaulf.

56. Hymenolepis spicata (Linn. fil.), Pr.; C. Chr. Ind. 356.-Acrostichum spicatum, Linn. fil.; Baker, Fl. Maur. 514.

Seychelles (fide Baker, not seen).

Spread through the tropics of the Old World, continental Africa excluded; common in the South-east African islands.

57. Polypodium Pervillei, Mett.; Kuhn, Fil. Afr. 150; Baker, Trans. R. Irish Acad. xxv. tab. $31 \mathrm{~A}$; Fl. Maur. 504; C. Chr. Ind. 552.

Mahé, Pervillé! Gardiner! On rocks in streams or damp tree-trunks over 1000 feet. Endemic. 
58. Polypodidm Serrulatum (Sw.), Mett.; Baker, Fl. Maur. 504; C. Chr. Ind. 563. Mahé, Thomasset!

Distribution according to Hieronymus ('Hedwigia,' vol. xliv. 80) :-Tropical America (common), tropical West Africa, Madagascar, Mascarenes, Seychelles.

59. Polypodidm albobrunneum, Baker, Fl. Maur. 505 ; C. Chr. Ind. 508.-P. sechellarum, part., Baker, Fl. Maur. 505.

Mahé, Horne, 681! 682! Gardiner! Thomasset! Silhouette, near the summit, scarce; epiphyte high up on trees.

Endemic.

$P$. sechellarum, Baker, was founded partly on a small sterile plant from Mahé (Horne, n. 194) and partly on a single leaf from Mauritius (Lady Barkly), both of which I have seen. The description in Fl. Maur. is evidently written from the Mauritian specimen, which belongs to a species distinct from $P$. albobrunneum. The specimen from Mahé is, I have no doubt, only a small sterile plant of $P$. albobrunneum; some of the rather numerous specimens collected by Gardiner agree exactly with it. P. sechellarum, Baker, is thus not known from the Seychelles, and the name therefore is very inappropriate.

60. Polypodium cultratum, Willd., var. elasticum (Bory).-P. elasticum, Bory. P. asplenifolium, var. minor, Mett.; Kuhn, Fil. Afr. 146. P. cultratum, Baker, Fl. Maur. 505.

Mahé, on tree-trunks over 2000 feet, rather scarce, Gardiner! Thomasset !

$P$. cultratum (type) is a tropical American species, and is also found in the island of Fernando Po, Guinea. The variety elasticum is apparently confined to the Mascarenes and Seychelles. It is very like the type, especially some of its smaller forms, but it is more hairy, with longer and shorter hairs mixed on the upper surface and along the margins.

61. Polypodium Punctatum (Linn.), Sw.; C. Chr. Ind. 557.-P. irioides, Lam.; Baker, Fl. Maur. 507.

Mahé, Thomasset!

Through the tropical regions of the Old World.

62. Polypodium Phymatodes, Linn.; Baker, Fl. Maur. 508 ; C. Chr. Ind. 553.

Mahé, Gardiner! Thomasset! Bird Island, in dry places, Fryer! Long Island, Gardiner! Silhouette, Gardiner!

Distribution. From South Africa through tropical Africa, Asia, Australia, and Polynesia to Corea.

63. Crclophords spissus (Bory), Desv. ; C. Chr. Ind. 201.-Polypodium spissum, Bory; Kuhn, Fil. Afr. 153. P. adnascens, Baker, Fl. Maur. 506.

Seychelles (fide Kuhn and Baker, not seen).

South Africa and the Eastern islands; scattered through tropical Asia. 
64. Elaphoglossum martinicense (Desv.), T. Moore, var. obtusum, C. Chr. (var. nov.).Acrostichum simplex, var. martinicense, Baker, Fl. Maur. 510.

Mahé, Horne, 676! Gardiner! Not uncommon in Mahé and Silhouette (Horne).

Differs from the typical $E$. martinicense of the West Indies, which certainly is specifically different from $E$. simplex, by the shortly acute or rounded-obtuse apex of the lamina (not long and gradually acuminate) and by the long decurrent base of the sterile frond, the stipe being winged nearly to the base. Sterile lamina $10-20 \mathrm{~cm}$. long by $1 \mathrm{~cm}$. broad, very coriaceous; fertile lamina shorter but of the same breadth on a much longer stipe. This variety may be the same as Acrostichum lineatum, Kuhn (Christ. Mon. Elaph. 146), from Madagascar, but that is said to have a stipe $10 \mathrm{~cm}$. long. Other similar forms are found in tropical West Africa. The true E. martinicense is probably confined to the West Indian islands.

65. Elaphoglossum conforme (Sw.), Schott; C. Chr. Ind. 304.--Acrostichum conforme, Sw.; Baker, Fl. Maur. 511.

Mahé and Silhouette, Gardiner!

Through the tropical regions.

66. Elaphoglossum latifolium (Sw.), J. Sm.; C. Chr. Ind. 309.-Aorostichum latifolium, Sw. ; Baker, Fl. Maur. 511.

Mahé and Silhouette, Gardiner !

I follow Baker in referring the fern in question to $E$. latifolium, which by some authors is considered an exclusively American species. I really cannot see how the specimens can be safely distinguished from the American form. Christ, in his monograph of the genus, refers all the large glabrous forms of Elaphoglossum from the South-east African islands to $E$. Sieberi (Hook. \& Grev.); but that species is said to have linear-subulate, almost black scales; our specimens have, however, light brown lanceolate scales, resembling those of the genuine $E$. latifolium. I am inclined to believe that the form from the Seychelles is just the same as Acrostichum ellipticum, Fée, Acrost. tab. 4, referred by Baker to $E$. Sieberi; Fée describes the scales as " aurantiaco-rufidulis." It resembles also very much the Javan $E$. callifolium (Blume), T. Moore. Kuhn (Bot. v. Ost-Afr. 69) lists E. Sieberi among the ferns of the Seychelles, but his $A$. Sieberi is no doubt the same as $E$. latifolium as understood here.

- E. latifolium is widely distributed in tropical America; a form very much resembling that from the Seychelles is known from the Comoros.

67. Elaphoglossum Hornei, C. Chr. (sp. nov.). (Pl. 25, figs. 4-7.)

Syn. : Acrostichum viscosum, var. glabrescens, Baker, Fl. Maur. 512 (non A. glabrescens, Kuhn).

Rhizoma breviter repens, paleis rufis crispis anguste linearibus subintegris denso onustum. Stipites dense fasciculati, stricti, parce paleacei denique nudi, $1 \frac{1}{2}-2 \mathrm{~mm}$. crassi, 5-7 cm. longi. Lamina sterilis lanceolata, usque ad $35 \mathrm{~cm}$. longa, medio $4 \mathrm{~cm}$. lata, apice breviter attenuata, acuta, basi longe cuneata, papyracea vel subcoriacea, præter costam paleis minutis rufis laceratis subtus parce instructam ubique 
nuda. Vence plerumque furcatæ, intra marginem callosam apicibus subclavatis desinente. Lamina fertilis similis, $15-17 \mathrm{~cm}$. longa, $2 \mathrm{~cm}$. lata, stipite longiore $(10 \mathrm{~cm}$.$) .$

Mahé, Horne, 171! (type), Gardiner! Silhouette, 2000 feet, Gardiner!

I cannot agree with Baker in regarding this as a variety of $E$. petiolatum. It differs from that species in its much larger leaves, its glabrous surfaces, and the different scales of the rhizome. In E. petiolatum the scales are dark brown, glossy, very narrow, and nearly hair-like. In general habit our new species resembles not a little E. flaccidum.

68. Elaphoglossum petiolatum (Sw.), Urb., var. salicifolium (Willd.).-Acrostichum salicifolium, Willd. A. viscosum, Baker, Fl. Maur. 512.

Mahé and Silhouette, Gardiner!; apparently common.

Most specimens are rather densely clothed all over both surfaces with minute pseudostellate scales.

E. petiolatum type is common in tropical America; the variety is frequent in the South-east African islands, and Kuhn refers specimens from tropical West Africa to it. Very similar forms occur in Southern China and the Himalaya (A. neriifolium, Wall.).

69. Elaphoglossum spathulatum (Bory), T. Moore; C. Chr. Ind. 316.-Acrostichum spathulatum, Bory ; Baker, Fl. Maur. 512.

Mahé, Horne (fide Baker, not seen).

Distribution. South Africa with the adjacent islands, Ceylon, tropical America.

70. Acrostichum adreum, Linn.; Baker, Fl. Maur. 514; C. Chr. Ind. 5.

Seychelles; Mahé, Gardiner! Silhouette, Gardiner! Bird Island, Fryer! Aldabra Group, near Pte. Hodone, R. Dupont, 36 !

71. Platycerium bifurcatum (Cav.), C. Chr. Ind. 496.-P. alcicorne, Baker, Fl. Maur. 515.

Seychelles (fide Baker, not seen).

East Africa and islands, Australia and New Caledonia, Lord Howe Island.

As suggested in my 'Index,' it is uncertain whether this East-African Platycerium is the same as the true P. bifurcatum from Australia.

\section{PARKERIACE $\approx$.}

72. Ceratopteris thalictroides (Linn.), Brongn.; C. Chr. Ind. 169.

Mahé, Anse Royale, and Terné, Gardiner! Silhouette, Grande Barbe, Gardiner!

New to the Seychelles. The true C. thalictroides is widely distributed through the Old World tropics, and according to Benedict (Bull. Torr. Club, vol. xxxvi. (1906) 469) it is probably confined to the Old World, the American forms belonging to three different species. 


\section{GLEICHENIACE无.}

73. Gleichenia imenaris (Burm.), C. B. Clarke; C. Chr. Ind. 322.-G. dichotoma, Baker, Fl. Maur. 460.

Mahé, Silhouette, and Long Island, Gardiner !

Common through the tropical and subtropical regions of the Old World, and closely related forms occur in tropical America.

\section{SCHIZAACE}

74. Schizea digitata (Iinn.), Sw.; C. Chr. Ind. 616.-S. digitata, var. intermedia (Mett.), Baker, Fl. Maur. 516.

Mahé, Gardiner!

This is the genuine S. digitata, a species widely distributed through tropical Asia and Polynesia, but, so far as Africa is concerned, known from the Seychelles only. The locality Madagascar is doubtful. Baker referred the Seychelles specimens to S. intermedia, a species from New Caledonia distinctly different from $S$. digitata by having the sporangia intermixed with long paraphyses.

\section{MARATTIACEA.}

75. Marattia fraxinea, Sm.; C. Chr. Ind. 414.

Mahe, Gardiner! New to the group.

Distributed through the tropics of the Old World.

76. Angiopteris evecta (Forst.), Hoffm.; Baker, Fl. Maur. 517.

Mahé and Silhouette, Gardiner!

Widely spread through the Old World tropics.

\section{OPHIOGLOSSACE $Æ$.}

77. Ophioglossum Pendulum, Linn.; Baker, Fl. Maur. 517 ; C. Chr. Ind. 471.

Mahé, Gardiner! Thomasset! Silhouette, Gardiner! Apparently common.

Tropical Asia, Australia, and Polynesia, the South-east African islands, but not known from the African continent.

78. Ophioglossum Palmatum, Linn.; Kuhn, Fil. Afr. 178 ; C. Chr. Ind. 471.

Seychelles, Pervillé (fide Kuhn, not seen).

Florida and tropical America; Madagascar, Réunion, and Seychelles.

\section{EXPLANATION OF PLATE 25.}

Fig. 1. Asplenium complanatum, natural size.

2. Portion of pinna enlarged, showing sori.

3. Sporangium, enlarged.

4. Elaphoglossum Hornei, natural size.
Fig. 5. Portion of frond, showing venation.

6. Part of fertile frond, enlarged.

7. Sporangium, much enlarged. 
Percy Sladein Trust Expedition. (Christensen)
Trans LinN Soc Ser. 2. Z o C L Vol XV. P1. 25.
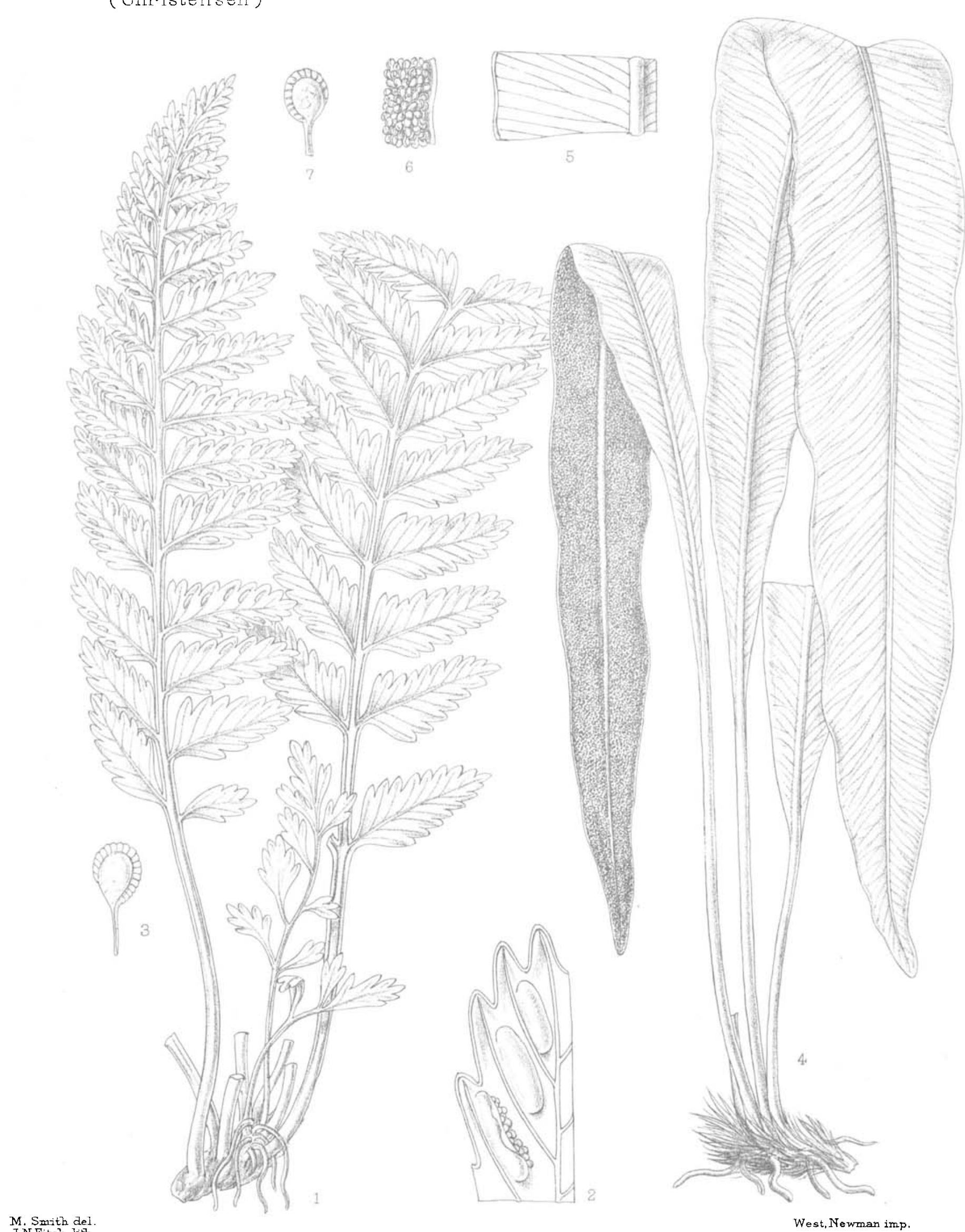

M. Smith del.

1-3 ASPLENIUM COMPLANATUM.

4. -7 FLAPHOGLOSSUM HORNEI. 